\title{
From confident medical students to confident doctors through exposure to simulated and clinical resuscitation
}

This article was published in the following Dove Press journal: Advances in Medical Education and Practice

\author{
Mohammad Yusuf \\ Abdoolraheem' \\ Mohammad Farwana ${ }^{2}$ \\ 'GKT School of Medical Education, \\ King's College London, UK; ${ }^{2}$ Frimley \\ Health Foundation Trust, Camberley, \\ UK
}

\section{Dear editor}

We read with great interest the research article published by Aggarwal and Khan ${ }^{1}$ concerning the experiences of final-year medical students in terms of both cardiopulmonary resuscitation (CPR) and discussions of advanced directives during clinical placements. While we would agree with the concluding opinion that there should be standardized formal education concerning CPR and "Do Not Attempt CPR" (DNACPR); the knowledge and skills developed during theoretical and simulation-based teaching should also be complemented by clinical exposure to various scenarios such that the students are more prepared prior to starting their Foundation year training.

We disagree with the authors that "mannequin-based training" in formal courses, such as Basic Life Support (BLS), Intermediate Life Support (ILS), and Advanced Life Support (ALS), does not prepare the learner for the "realities of an arrest call". Furthermore, our experiences of BLS, ILS, and ALS have been invaluable in preparing us for the roles we have played during an active resuscitation attempt. The repetitive presence of supervised, teamwork-based simulations during our medical education was crucial in providing us with the confidence, knowledge, and the communication skills required for an effective resuscitation in accordance with the Resuscitation Council (UK) Advanced Life Support guidelines. We do, however, agree that more content/training should be placed in these courses to highlight the physical and emotional feedbacks received from active CPR, as well as the ethical decisions involved in starting and stopping CPR.

Given that medical students are expected to be able to "provide cardiopulmonary resuscitation or direct other team members to carry out resuscitation" according to the General Medical Council's "Outcomes for Graduates", ${ }^{2}$ we believe it would be ideal for all students to have encountered a crash call in some context by the end of their medical education. From a practical perspective, it would be ideal for students to undergo simulated training concerning adult BLS/ALS prior to starting their clinical placements and for students to be competent in performing CPR in the hospital and community. Studies have shown an improvement in the confidence of students following simulation-based teaching, with one study of 115 third-year medical students demonstrating $47 \%-100 \%$ retention of the procedures 1 year later, highlighting the value of simulation training in preparing students. ${ }^{3}$ However, it
Correspondence: Mohammad Yusu Abdoolraheem

GKT School of Medical Education, King's College London, Hodgkin Building,

Newcomen Street, London SEI IUL, UK

Tel +4474I5416663

Email kI328933@kcl.ac.uk 
is advisable that students should attend annual refresher courses to maintain competency. ${ }^{4}$

It is unsurprising that there are limited student experiences of discussions concerning DNAPCR, since this is not explicitly referenced in "Outcomes for Graduates", 2 despite this aspect of patient care being increasingly relevant in the aging and increasingly comorbid population. We believe that during medical school, there needs to be greater emphasis on end-of-life care, DNACPR orders, and discussions with the family. We believe that by increasing the amount of theoretical and simulated education concerning the unwell patient, cardiac arrests, and end-of-life care discussions during medical school, we can increase student exposure to such conversations, thus preparing them for ward-based care.

\section{Disclosure}

The authors report no conflicts of interest in this communication.

\section{References}

1. Aggarwal A, Khan I. Medical students' experiences of resuscitation and discussion surrounding resuscitation status. Adv Med Educ Pract. 2018;9:31-37.

2. General Medical Council. Outcomes for Graduates. Manchester: General Medical Council; 2015. Available from: https://www.gmc-uk.org/ Outcomes_for_graduates_Jul_15_1216.pdf_61408029.pdf. Accessed April 11, 2018.

3. Ander DS, Heilpern K, Goertz F, Click L, Kahn S. Effectiveness of a simulation-based medical student course on managing life-threatening medical conditions. Simul Healthc. 2009;4(4):207-211.

4. Avisar L, Shiyovich A, Aharonson-Daniel L, et al. Cardiopulmonary resuscitation skills retention and self-confidence of preclinical medical students. Isr Med Assoc J. 2013;15(10):622-627.

Dove Medical Press encourages responsible, free and frank academic debate. The content of the Advances in Medical Education and Practice 'letters to the editor' section does not necessarily represent the views of Dove Medical Press, its officers, agents, employees, related entities or the Advances in Medical Education and Practice editors. While all reasonable steps have been taken to confirm the content of each letter, Dove Medical Press accepts no liability in respect of the content of any letter, nor is it responsible for the content and accuracy of any letter to the editor.

\section{Publish your work in this journal}

Advances in Medical Education and Practice is an international, peerreviewed, open access journal that aims to present and publish research on Medical Education covering medical, dental, nursing and allied health care professional education. The journal covers undergraduate education, postgraduate training and continuing medical education including emerging trends and innovative models linking education, research, and health care services. The manuscript management system is completely online and includes a very quick and fair peer-review system. Visit http://www.dovepress.com/testimonials.php to read real quotes from published authors.

Submit your manuscript here: http://www.dovepress.com/advances-in-medical-education-and-practice-journal 